\title{
Studies towards the Construction of Quaternary Indolizidines by [2,3]-Sigmatropic Rearrangement Cocatalyzed by Ionic Liquid
}

\author{
Esteban F. Duran-Lara, Nagula Shankaraiah, Daniela Geraldo and Leonardo S. Santos* \\ Laboratory of Asymmetric Synthesis, Chemistry Institute of Natural Resources, \\ Universidad de Talca, Talca, P.O. Box 747, Chile
}

\begin{abstract}
Uma abordagem enantiosseletiva eficiente para a preparação de centros quaternários a partir da prolina $\mathbf{5}$ foi desenvolvida através do rearranjo [2,3]-sigmatrópico de Stevens, co-catalisado por líquido iônico. O rearranjo sigmatrópico foi estereoespecífico porque as migrações-[2,3] foram restritas à mesma face e a estereosseletividade surgiu na etapa preliminar da $N$-alquilação em $\mathbf{8}$. O método mostrou melhores rendimentos do que os descritos na literatura. $\mathrm{O}$ uso de hexafluorofostato de 1-butil-3-metilimidazólio mostrou uma melhora nos rendimentos do rearranjo de Stevens devido a possível estabilização e/ou ativação das espécies zuiteriônicas em solução, pelo líquido iônico. Diversas indolizidinas foram sintetizadas a partir do derivado $(S)-\mathbf{5}$ da prolina quaternária.
\end{abstract}

An efficient enantioselective approach for preparation of quaternary centers from proline $\mathbf{5}$ building block has been developed through [2,3]-sigmatropic Stevens rearrangement co-catalyzed by ionic liquid. The sigmatropic rearrangement was stereospecific because the [2,3]-migrations were restricted to the same face, and the stereoselectivity arose from the previous $N$-alkylation step in 8. The approach showed better yields than described in literature. The use of 1-butyl-3methylimidazolium hexafluorophosphate showed an improvement in the yields of the Stevens rearrangement due to a possible stabilization and/or activatation of zwiterionic species in solution by the ionic liquid. Several indolizidine moieties were synthesized from quaternary proline derivative $(S)-\mathbf{5}$.

Keywords: Stevens rearrangement, [2,3]-sigmatropic, indolizidines, ionic liquid, co-catalyzed

\section{Introduction}

Chirality in molecules plays an enormous role in areas ranging from medicine to material science. However, after great developments in synthetic organic chemistry, there are still few methodologies that allow the stereoselective construction of predetermined moieties in some classes of compounds. In this context, particular attention in efficient synthetic routes for novel chemotypes is already pursued when stereoselectivity is required. As part of our efforts in the field of biologically relevant N-moieties, we turned our attention toward an alternative synthetic route for indolizidines, figured out through key intermediate $(S)-\mathbf{5}$, as depicted in Figure 1. Quaternary proline derivatives are important amino acids due to the pharmacological applicability of natural peptides is greatly limited by

\footnotetext{
*e-mail: 1ssantos@utalca.cl
}

profound factors such as lack of selectivity for a specific receptor, enzymatic instability, or low bioavailability. ${ }^{1}$ Most vital physiological processes by the construction of several peptides and proteins are therefore targets for potential medical applications across the full spectrum of human disease. ${ }^{2}$ A number of strategies devised for the synthesis of $\alpha$-substituted proline derivatives involve the $\alpha$-functionalization of L-proline itself. Most often, the assembly of the fully substituted stereocenter is accomplished by electrophilic alkylation of L-proline enolate equivalents. ${ }^{3}$ The asymmetric construction of molecules with quaternary carbon stereocenters, that is, carbon centers with four different non-hydrogen substituents, represents a very challenging and dynamic area in organic synthesis. Chirality transfer from carbon to carbon via sigmatropic rearrangements is a well-established approach in asymmetric synthesis. ${ }^{4}$ However, the classic methodologies are being substituted more and more by 


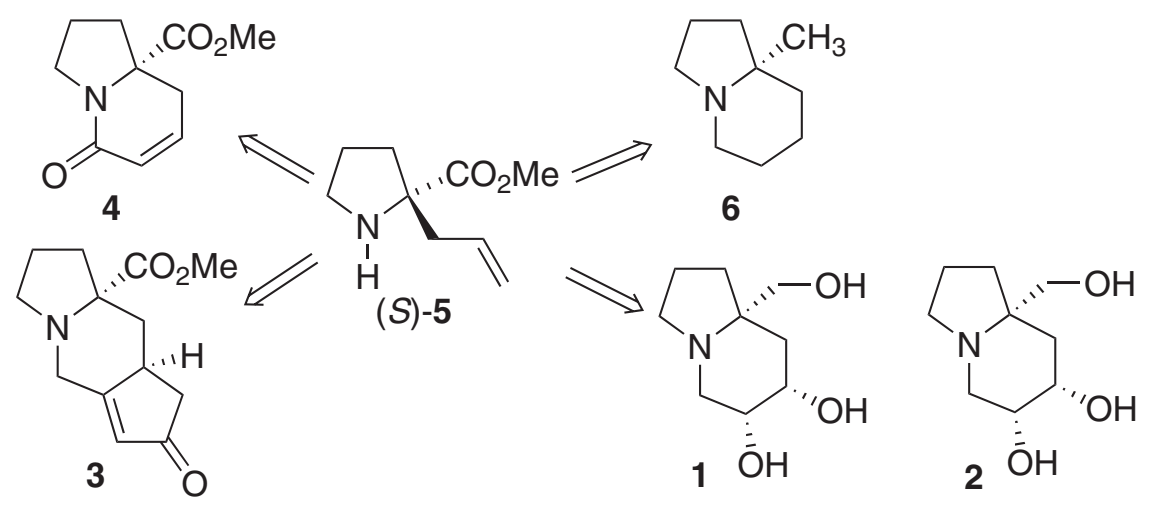

Figure 1. Quaternary indolizidines through key intermediate $(S)$-5.

catalytic and modern processes. Thus, we figured out to explore $\mathrm{N} \rightarrow \mathrm{C}$ chirality transfer under [2,3]-shift of proline derivative ammonium ylides stereogenic at nitrogen.

$(S)$-Allylproline methyl ester ${ }^{5}$ is an important building block for the total synthesis of the fungal metabolites (-)-stephacidin A, (+)-stephacidin B, and (+)-notoamide $\mathrm{B}$, quaternary indolizines and indolizidinones (Figure 1), and we turned our attention toward an alternative synthetic route for $(S)$-5, figured out through key intermediate $(S)-\mathbf{9}$, and features the Stevens sigmatropic rearrangement cocatalyzed by ionic liquids (Scheme 1).

\section{Results and Discussion}

We first explored the Stevens rearrangement ${ }^{6}$ of the preformed iminium 8 co-catalyzed by ionic liquid. It was suggested that ionic liquids can activate and stabilize zwiterionic species in solution. ${ }^{7}$ Thus, iminium 8 was obtained in $75 \%$ overall yield from $N$-benzylproline methyl ester $7,{ }^{8}$ which was alkylated stereoselectively with allyl bromide and fractionally crystallized (Scheme 2). Having prepared iminium $\mathbf{8}$, the next stage was set to introduce the allyl group $\alpha$-nitrogen selectively through Stevens rearrangement and the role of co-catalysis by the ionic liquid 1-butyl-3-methylimidazolium hexafluorophosphate
[BMIm] $\mathrm{PF}_{6}{ }^{9}$ studied to give 9, Table 1 . In all the examples described, just stereospecific [2,3]-sigmatropic rearrangement was observed in the migration of the allyl group from $\mathbf{8}$, and no competing [1,2]-sigmatropic rearrangement was detected, although it has been observed in some cases for allyl-substituted ammonium ylides. ${ }^{10} \mathrm{It}$ was previously reported that allyl-migration using $\mathrm{K}_{2} \mathrm{CO}_{3}$ afforded 9 in low yield (40\%) and good enantioselectivities (entry 1 , Table 1). ${ }^{11}$ Then, using [BMIm] $\cdot \mathrm{PF}_{6}$ as co-catalyst it was observed the same selectivity, but in a better yield of $50 \%$ (Table 1, entry 2). Trying to improve the yields we set out the use of stronger bases in different solvents and co-catalysis by ionic liquid (Table 1). When NaHMDS was employed using THF as solvent an improvement in the yields was achieved as well as higher enantiomeric excesses than $\mathrm{K}_{2} \mathrm{CO}_{3}(90 \%$ ee, Table 1, entry 3 ). Testing the co-catalysis by $[\mathrm{BMIm}] \cdot \mathrm{PF}_{6}$ showed a significative improvement in the yields and no influence in the selectivities (entries 4, 6, 8-13 and 15) as depicted in Table 1. Product (S)-9 was obtained as the major enantiomer in all the studied cases (Table 1), consistent with the notion that when an prenyl group is added to 7 a [2,3]-shift mechanism is ongoing and would be restricted to the same face of proline derivative, due to the trans arrangement of the benzyl and ester groups. Stereospecificity for exclusive [2,3]-shifts of a prenyl

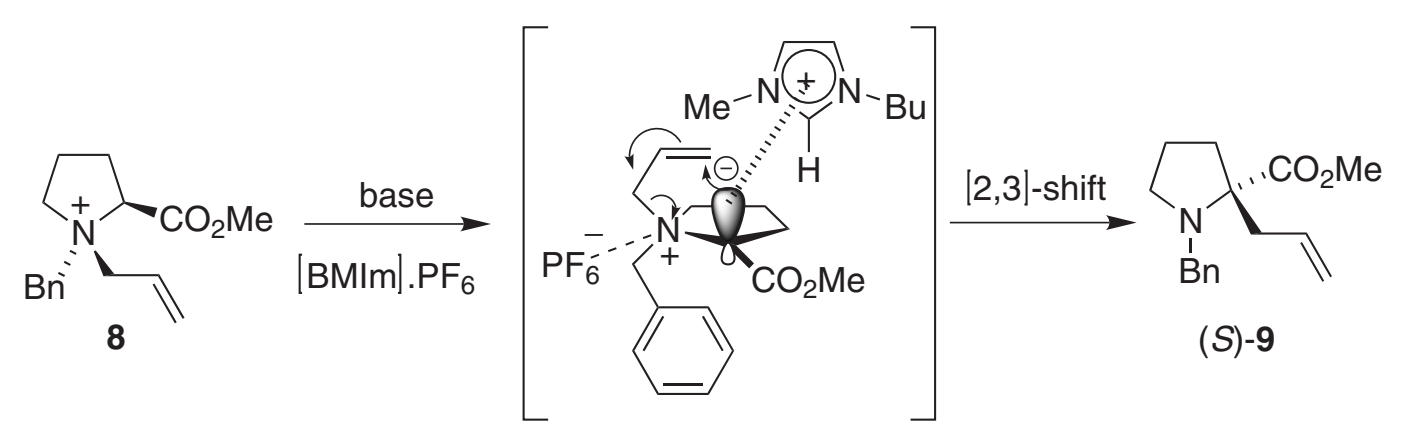

Scheme 1. Proposed mechanism for ionic liquid stabilization of zwiterionic species in the Stevens [2,3]-sigmatropic rearrangement. 
Table 1. Reagents and conditions used in the Stevens rearrangement of 8 to afford 9 cocatalyzed by ionic liquid ${ }^{\mathrm{a}}$

\begin{tabular}{|c|c|c|c|}
\hline Entry & Condition & $e e /(\%)$ & Yield / (\%) \\
\hline 1 & $\mathrm{~K}_{2} \mathrm{CO}_{3}, \mathrm{DMF}, \mathrm{rt}$ & $85^{\mathrm{b}}$ & $40^{\mathrm{b}}$ \\
\hline 2 & $\mathrm{~K}_{2} \mathrm{CO}_{3},[\mathrm{BMIm}] \cdot \mathrm{PF}_{6}, \mathrm{DMF}, \mathrm{rt}$ & 85 & 50 \\
\hline 3 & NaHMDS, THF, $-78^{\circ} \mathrm{C}$ & 90 & 62 \\
\hline 4 & NaHMDS, $[\mathrm{BMIm}] \cdot \mathrm{PF}_{6}, \mathrm{THF},-78^{\circ} \mathrm{C}$ & 90 & 78 \\
\hline 5 & NaHMDS, THF, $-78^{\circ} \mathrm{C}$ & 88 & 58 \\
\hline 6 & $\begin{array}{l}\mathrm{NaHMDS},[\mathrm{BMIm}] \cdot \mathrm{PF}_{6}, \mathrm{MeCN}, \\
-78^{\circ} \mathrm{C}\end{array}$ & 88 & 68 \\
\hline 7 & $\mathrm{DBU}, \mathrm{MeCN}, 0^{\circ} \mathrm{C}$ & 50 & 55 \\
\hline 8 & $\mathrm{DBU},[\mathrm{BMIm}] \cdot \mathrm{PF}_{6}, \mathrm{MeCN}, 0^{\circ} \mathrm{C}$ & 65 & 80 \\
\hline 9 & $\mathrm{DBU},[\mathrm{BMIm}] \cdot \mathrm{PF}_{6}, \mathrm{MeCN}, \mathrm{rt}$ & 60 & 68 \\
\hline 10 & $\mathrm{DBU},[\mathrm{BMIm}] \cdot \mathrm{PF}_{6}, \mathrm{MeCN}$, reflux & 88 & 65 \\
\hline 11 & $\mathrm{DBU},[\mathrm{BMIm}] \cdot \mathrm{PF}_{6}, \mathrm{THF}, 0{ }^{\circ} \mathrm{C}$ & 60 & 75 \\
\hline 12 & DBU, $[\mathrm{BMIm}] \cdot \mathrm{PF}_{6}, \mathrm{THF}, \mathrm{rt}$ & 80 & 70 \\
\hline 13 & DBU, [BMIm] $\mathrm{PF}_{6}, \mathrm{THF}$, reflux & 65 & 58 \\
\hline 14 & $\mathrm{KO} \mathrm{B}^{\prime} \mathrm{Bu}, \mathrm{DMF}, \mathrm{rt}$ & $85^{\mathrm{b}}$ & $40^{\mathrm{b}}$ \\
\hline 15 & $\mathrm{KO}^{\prime} \mathrm{Bu},[\mathrm{BMIm}] \cdot \mathrm{PF}_{6}, \mathrm{DMF}, \mathrm{rt}$ & 85 & 50 \\
\hline
\end{tabular}

a[BMIm] $\mathrm{PF}_{6}$ : 1-butyl-3-methylimidazolium hexafluorophosphate.

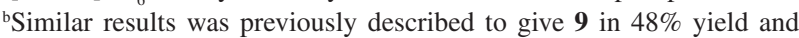
$86 \%$ ee. ${ }^{11}$

group derivative had previously been reported by West and Glaeske ${ }^{12}$ and by Coldham and co-workers, ${ }^{11}$ respectively. Then, benzyl group deprotection of 9 using $\mathrm{Et}_{3} \mathrm{SiH} / \mathrm{PdCl}_{2}$ in $\mathrm{CH}_{2} \mathrm{Cl}_{2}{ }^{13}$ afforded $\mathbf{5}$ in quantitative yield.

To further illustrate the versatility of this methodology, the diallyl derivatives $\mathbf{1 0}$ was obtained by allylation of $\mathbf{5}$, followed by a ring-closing metathesis ( $5 \mathrm{~mol} \%$ of Grubbs third generation catalyst, $25{ }^{\circ} \mathrm{C}, \mathrm{CH}_{2} \mathrm{Cl}_{2}$ ) to afford the indolizidine $\mathbf{1 1}$ in excellent yields. ${ }^{14}$ Reduction of methyl ester employing $\mathrm{LiAlH}_{4}$ in refluxing THF afforded the alcohol with concomitant olefinic bond reduction in $86 \%$ overall yield (Scheme 3). The dehydroxylation to achieve $6^{15}$ was carried out using $\mathrm{PBr}_{3}$ followed by AIBN and $\mathrm{Et}_{3} \mathrm{SiH}$ treatment ( $82 \%$ in two steps). It was also tested the reduction of the bromide derivative $\mathbf{1 4}$ with $\mathrm{LiAlH}_{4}$ in THF and reflux, but it was observed lower yields (56\%) when compared with radical AIBN/Et ${ }_{3} \mathrm{SiH}$ protocol. The cis-dihydroxylation of $\mathbf{1 1}$ using catalytic osmium tetroxide $\left(\mathrm{OsO}_{4}\right)$ and $\mathrm{N}$-methylmorpholine $\mathrm{N}$-oxide (NMO) in THF: $\mathrm{H}_{2} \mathrm{O}$ afforded the diastereomeric diols $\mathbf{1 2}$ and $\mathbf{1 3}$ (90\%) in a 5:1 $d r$ (Scheme 3). The facial selectivity in the osmylation can be rationalized in terms of the concavity of the indolizidine system, which proceeded through the less hindered face. ${ }^{16}$ Diols $\mathbf{1 2}$ and $\mathbf{1 3}$ were unseparated by chromatography, and to prove the absolute configuration of the dihydroxylation step of products $\mathbf{1 2}$ and $\mathbf{1 3}$, reduction of methyl ester was performed. Thus, reduction of $\mathbf{1 2}$ and 13 with alane $\left(\mathrm{AlH}_{3}\right)$ gave after silica gel purification $\mathbf{1}$ and 2 in $92 \%$ and $95 \%$ yield, respectively. ${ }^{17}$ This route provides enantiomerically pure 1-azabicyclo[4.3.0]nonane.

Further, with an efficient approach to quaternary indolizidine established by Grubbs catalyst, the stage was now set for the indolizidinone moiety. Treatment of (S)-5 and acrylic acid with EDC and $\mathrm{HOBt}$ in $\mathrm{CH}_{2} \mathrm{Cl}_{2}$ gave $\mathbf{1 5}$ in $92 \%$ yield (Scheme 4 ). ${ }^{18}$ Metathesis reaction of $\mathbf{1 5}$ with Grubbs catalyst afforded 4 in 80\% (90\% ee), as depicted in Scheme 4. The enantiomeric excesses were determined by HPLC to assure that no epimerization was occurred in the process. ${ }^{19}$

Finally, allyl proline $\mathbf{5}$ can be converted to $\mathbf{1 6}$ using NaHMS and 1-bromopronyn in $95 \%$ yield. ${ }^{20}$ In the course of our investigation, the stoichiometric use of $\mathrm{Co}_{2}(\mathrm{CO})_{8}$ for the intramolecular amine oxide promoted Pauson-Khand reaction in the ionic liquid $[\mathrm{BMIm}] \mathrm{PF}_{6}$ was studied. Pauson-Khand reaction using 16, catalytic amount of $\mathrm{Co}_{2}(\mathrm{CO})_{8}(10 \mathrm{~mol} \%)$, cocatalyzed with [BMIm] $\mathrm{PF}_{6}$ under $\mathrm{CO}$ atmosphere (1.0 bar) afforded tricyclic enone 3 in $89 \%$ yield as a single stereoisomer, as depicted in Scheme 5. The reaction was performed using catalytic amount of cobalt (0) octacarbonyl in THF in the presence of NMO as promoter. $^{21}$

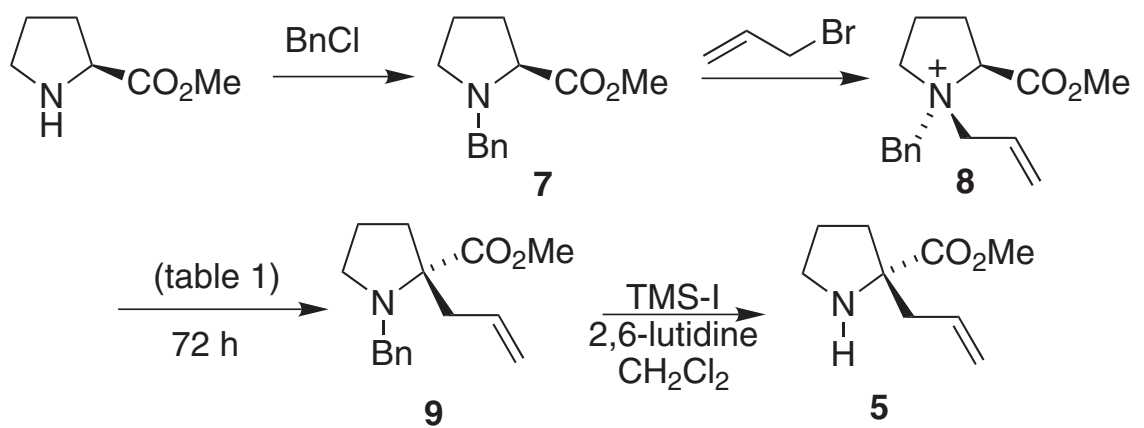

Scheme 2. Stevens sigmatropic rearrangement and synthesis of (S)-allylproline derivative $\mathbf{5}$. 
5<smiles>C=CCN1CCC[C@]1(CC=C)C(=O)OC</smiles>

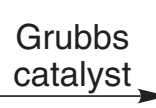

10<smiles>COC(=O)[C@]12CC=CCN1CCC2</smiles>

11

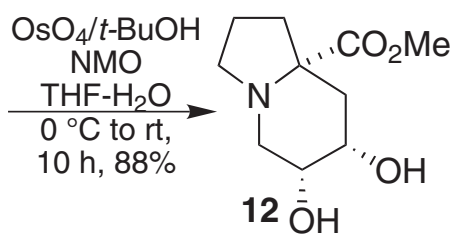

12 Ò $\mathrm{H}$

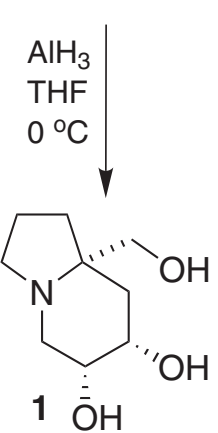<smiles>CC(=O)[C@]12CCCN1C[C@H](O)[C@@H](O)C2</smiles>

$(5: 1)$

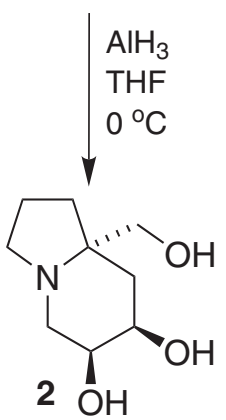

Scheme 3.<smiles>C=CC[C@]1(C(=[OH+])OC)CCCN1</smiles>

5

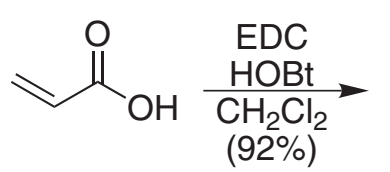

(92\%)<smiles>C=CC[C@]1(C(=O)OC)CCCN1C(=O)C=C</smiles><smiles>COC(=O)C12CC=CC(=O)N1CCC2</smiles>

Scheme 4.

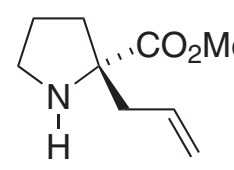

5

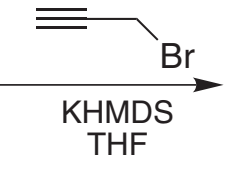

95\%<smiles>C#CCN1CCC[C@]1(CC=C)C(=O)OC</smiles>

1) $\mathrm{CO}$ (1.0 bar)

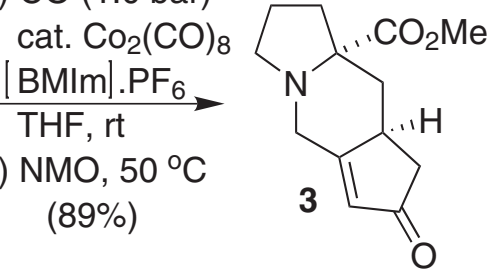

Scheme 5.

\section{Conclusions}

In summary, a mild and efficient method for preparation of quaternary centers from proline 5 building block has been developed. The Stevens rearrangement was stereospecific because the [2,3]-migrations was restricted to the same face, and the stereoselectivity arose from the previous $\mathrm{N}$-alkylation step. For the first time, the use of 1-butyl3-methylimidazolium hexafluorophosphate showed an improvement in the yields of the Stevens rearrangement due to a possible stabilization and/or activatation of zwiterionic species in solution by the ionic liquid. The results described here provide an attractive route to 8a-substituted indolizidines, and the utilization of this approach in the total synthesis of different alkaloids is undergoing in our laboratory.

\section{Experimental}

\section{General procedures}

All experiments were carried out under an argon atmosphere except for hydrolysis under acid conditions. Dichloromethane was distilled from $\mathrm{CaH}_{2}$, tetrahydrofuran previously treated with $\mathrm{CaH}_{2}$ and distilled from sodium, methanol was distilled from $\mathrm{Mg}$ tunings. The normal extracts consisted of drying over $\mathrm{MgSO}_{4}$, filtration and concentration under reduced pressure with a rotatory 
evaporator. The compounds were purified by column chromatography on silica gel (70-230 mesh). The ${ }^{1} \mathrm{H}$ NMR and ${ }^{13} \mathrm{C}$ NMR spectra were recorded on a Bruker $(400 \mathrm{MHz})$ spectrometer. Chemical shifts $(\delta)$ are recorded in ppm with the solvent resonance as the internal standard and coupling constants $(J)$ recorded in Hz. Signals for rotational and/or configuration isomers are denoted inside brackets. The infrared spectra were recorded as films in $\mathrm{KBr}$ cells on a Nicolet Nexus 470 (FTIR). Mass spectrometry experiments were performed on a highresolution high accuracy hybrid double quadrupole (Qq) and orthogonal time-of-flight (Tof) mass spectrometer (QTof, Micromass UK). The temperature of the nebulizer was $50{ }^{\circ} \mathrm{C}$. The ESI source and the mass spectrometer were operated in the positive-ion mode. The cone and extractor potential were set to 40 and $10 \mathrm{~V}$, respectively. Optical rotations were measured on a polarimeter Polamat A Carl Zeiss Jena using a quartz cell and a mercury or sodium lamp. The melting points were measured on an Eletrothermal 9100 apparatus. The gas chromatography analyses (FID detector) were performed using a Shimazu equipment. Column chromatography was performed using silica gel Merck 230-400 mesh. TLC analyses were performed with silica gel plates Merck using iodine, $\mathrm{KMnO}_{4}$ and UV-lamp for visualization.

\section{Preparation of 8}

Allyl bromide $(60 \mathrm{mmol})$ was added neat to 7 (6.57 g, $30 \mathrm{mmol}$ ), and the mixture was stirred for $2 \mathrm{~h}$. Excess allylbromide was removed under reduced pressure, and the brown residue was dissolved in $\mathrm{CH}_{2} \mathrm{Cl}_{2}(150 \mathrm{~mL})$ and layered with $\mathrm{Et}_{2} \mathrm{O}(200 \mathrm{~mL})$. Three recrystallizations $\left(\mathrm{CH}_{2} \mathrm{Cl}_{2} / \mathrm{Et}_{2} \mathrm{O}\right)$ provided $\mathbf{8}$ in $75 \%$ as white needles: $\mathrm{mp}$ 123-124 ${ }^{\circ} \mathrm{C} ;[\alpha]_{\mathrm{D}}=-12.0\left(c 0.2, \mathrm{CHCl}_{3}\right)$; FT-IR $(\mathrm{KBr})$ $v_{\max } / \mathrm{cm}^{-1}: 2970,1762,1450$. HRMS, ESI(+)-MS: $m / z$ calc. for $\left[\mathrm{C}_{16} \mathrm{H}_{22} \mathrm{NO}_{2}\right]^{+}$260, 1651; found: $m / z, 260,1648$.

\section{General procedure for Stevens rearrangement, preparation of 9}

Solid $\mathrm{K}_{2} \mathrm{CO}_{3}(112 \mathrm{mg}, 1.0 \mathrm{mmol})$ was added to a solution of $\mathbf{8}(1.0 \mathrm{mmol})$ in DMF $(1.0 \mathrm{~mL})$, and the reaction was stirred at $0-5^{\circ} \mathrm{C}$ for $72 \mathrm{~h}$; then the solution was filtered through a Celite plug and concentrated to give a white residue. Recrystallization $\left(\mathrm{CH}_{2} \mathrm{Cl}_{2} / \mathrm{Et}_{2} \mathrm{O}\right)$ provided 9 in $85 \%$ ee $[\alpha]_{\mathrm{D}}=-46\left(c 0.75, \mathrm{CHCl}_{3}\right)$ and is in accordance with described previously. ${ }^{11}$ The cocatalyzed reactions were performed as the procedure described above with addition of $[\mathrm{BMIm}] \cdot \mathrm{PF}_{6}(0.5 \% \mathrm{~mol})$. The enantiomeric excess of recrystallized 9 was determined by HPLC using a chiral column Welch-01 (hexane/2-propanol, 9:1, major 5.6 min and minor $7.3 \mathrm{~min}$ ).

\section{Preparation of iodotrimethylsilane (TMSI)}

To a mixture of (TMS $)_{2}(8.86 \mathrm{~g}, 8.19 \mathrm{~mL}, 40.0 \mathrm{mmol})$ and iodine $(10.2 \mathrm{~g}, 40.0 \mathrm{mmol})$ was heated to $65^{\circ} \mathrm{C}$ in a system equipped with a flask coupled to Vigreux column and two condensers, careful due to a high exothermic reaction took place. A homogenous solution was achieved. Then, the mixture was refluxed by $1.5 \mathrm{~h}$. (TMS) ${ }_{2}$ was converted quantitatively to TMSI.

\section{(S)-(+)-2-(2-Propenyl)proline methyl ester hydrochloride (5)}

Compound 9 (1.44 mmol) was dissolved in $40.0 \mathrm{~mL}$ of dry MeCN, and TMSI (0.823 mL, $5.78 \mathrm{~mol})$ was added dropwise at $0{ }^{\circ} \mathrm{C}$. The mixture was stirred for $1 \mathrm{~h}$ at $0{ }^{\circ} \mathrm{C}$. Under low temperature, it was added $30.0 \mathrm{~mL}$ of $\mathrm{HCl}(10 \%)$, extracted with $\mathrm{Et}_{2} \mathrm{O}(3 \times 20 \mathrm{~mL})$ to take off benzyliodide. Then, a $\mathrm{KOH}\left(6.0 \mathrm{~g}, 54 \mathrm{~mL} \mathrm{H} \mathrm{H}_{2} \mathrm{O}\right)$ was added dropwide to the acid solution. White precipitate was formed between $\mathrm{pH}$ 11-12. After extraction with $\mathrm{CH}_{2} \mathrm{Cl}_{2}$ (3-4x), drying and solvent evaporation under vacuum, $\mathbf{5}$ was obtained as white solids in $99 \%$ yield. ${ }^{1} \mathrm{H}$ NMR ( $\left.\mathrm{D}_{2} \mathrm{O}, 400 \mathrm{MHz}\right), \delta 1.98-2.20$ (4H, m), 2.45-2.52 (t), 2.61-2.69 (q), 2.91-2.98 (q), 3.32(s), 3.41-3.46 (1H, t), $3.85(3 \mathrm{H}, \mathrm{s}), 5.25-5.32(2 \mathrm{H}, \mathrm{t}), 5.60-5.80$ $(1 \mathrm{H}, \mathrm{m}) .{ }^{13} \mathrm{C}$ NMR (D $\left.\mathrm{O}, 100 \mathrm{MHz}\right), \delta 24.7,37.4,41.3$, $43.2,46.1,52.3,69.3,118.2,134.2,176.0$.

Dihydroxylation of 11 followed by ester reduction of 12 and 13

Osmium tetroxide $(67.0 \mu \mathrm{L}$ of a freshly prepared $0.039 \mathrm{~mol} \mathrm{~L}^{-1}$ solution in $t$ - $\left.\mathrm{BuOH}\right)$ was added to a solution of $11(0.775 \mathrm{mmol})$ and $\mathrm{N}$-methylmorpholine $\mathrm{N}$-oxide $\left(0.256 \mathrm{~mL}, 50 \%, \mathrm{v} / \mathrm{v}\right.$, in water) in a 9:1 $\mathrm{THF}-\mathrm{H}_{2} \mathrm{O}$ solution $(9.70 \mathrm{~mL})$ at $0{ }^{\circ} \mathrm{C}$. After $12 \mathrm{~h}$ at room temperature, the mixture was treated with Florisil $(0.350 \mathrm{~g})$ and $\mathrm{NaHSO}_{3}(0.111 \mathrm{~g})$, stirred for $1 \mathrm{~h}$, filtered, and concentrated. The residue was diluted with EtOAc, and the organic layer was washed with $5 \% \mathrm{H}_{3} \mathrm{PO}_{4}$ and brine, dried, and concentrated to give an unseparated 5:1 mixture of $\mathbf{8}$ and $\mathbf{9}$ in $88 \%$ yield. A solution of the isomers 12 and $\mathbf{1 3}(5: 1)(0.502 \mathrm{mmol})$ in dry THF $(6.0 \mathrm{~mL})$ was added a solution of $\mathrm{AlH}_{3}$ in $\mathrm{THF}\left(1.55 \mathrm{~mol} \mathrm{~L}^{-1}\right.$, $1.94 \mathrm{~mL}, 3.01 \mathrm{mmol})^{22}$ at room temperature. After $10 \mathrm{~min}$, the reaction was quenched with saturated aqueous sodium sulfate solution and filtered. The solids were washed with $\mathrm{CH}_{2} \mathrm{Cl}_{2}$ (200 mL), dried with $\mathrm{Na}_{2} \mathrm{SO}_{4}$, and evaporated in vacuum. Purification by chromatography afforded compound $\mathbf{1}$ and 2 in 75 and $15 \%$ yields, respectively.

(6R,7S,8aS)-6,7-Dihydroxy-8a-hydroxymethylindolizidine hydrochloride (1)

mp 198-200 ${ }^{\circ} \mathrm{C} .[\alpha]_{\mathrm{D}=}-8.0$ (c 1.0, $\left.\mathrm{H}_{2} \mathrm{O}\right)$. FTIR $(\mathrm{KBr})$ $v_{\max } / \mathrm{cm}^{-1}: 3330,3275,3230,3148,1475$. HRMS, ESI(+)- 
MS: calc. for $\mathrm{C}_{9} \mathrm{H}_{18} \mathrm{NO}_{3}+\mathrm{H}+$ : 188.1287 , found 188.1280 . ${ }^{1} \mathrm{H}$ NMR ( $\left.\mathrm{D}_{2} \mathrm{O}, 400 \mathrm{MHz}\right), \delta 1.68-1.85(2 \mathrm{H}, \mathrm{m}), 2.03(4 \mathrm{H}$, m), $3.15(2 \mathrm{H}, \mathrm{m}), 3.28(1 \mathrm{H}, \mathrm{dd}, J 13.5,4.4 \mathrm{~Hz}), 3.49(3 \mathrm{H}$, $\mathrm{m}), 4.63-3.94(2 \mathrm{H}, \mathrm{m}) .{ }^{13} \mathrm{C}$ NMR $\left(\mathrm{D}_{2} \mathrm{O}, 100 \mathrm{MHz}\right), \delta 19.6$, 30.3, 28.4, 52.9, 53.1, 63.8, 65.2, 65.9, 72.8. HRMS, ESI(+)-MS: $m / z$ calc. for $\left[\mathrm{C}_{9} \mathrm{H}_{18} \mathrm{NO}_{3}+\mathrm{H}\right]^{+} 188.1287$; found: 188.1289 .

(6S,7R,8aS)-6,7-Dihydroxy-8a-hydroxymethylindolizidine hydrochloride (2)

mp 200-202 ${ }^{\circ} \mathrm{C} .[\alpha]_{\mathrm{D}}=+11\left(\mathrm{c} 1.1, \mathrm{H}_{2} \mathrm{O}\right)$. FTIR $(\mathrm{KBr})$ $v_{\max } / \mathrm{cm}^{-1}: 3295,2965,2890,1460$. HRMS, ESI(+)-MS: $\mathrm{m} / \mathrm{z}$ calc. for $\left[\mathrm{C}_{9} \mathrm{H}_{18} \mathrm{NO}_{3}+\mathrm{H}\right]^{+} 188.1287$, found: 188.1280 . ${ }^{1} \mathrm{H}$ NMR ( $\left.\mathrm{D}_{2} \mathrm{O}, 400 \mathrm{MHz}\right), \delta 1.70(1 \mathrm{H}, \mathrm{dd}, J 14.1, J 4.0)$, 2.06-1.75 $(5 \mathrm{H}, \mathrm{m}), 3.13(1 \mathrm{H}, \mathrm{dd}, J 14.1, J 2.5), 3.30(1 \mathrm{H}$, dd, $J 14.1, J 4.0), 3.32-3.48(1 \mathrm{H}, \mathrm{m}), 3.50(1 \mathrm{H}, \mathrm{d}, J 12.1)$, $3.59(1 \mathrm{H}, \mathrm{d}, J 12.1), 3.68-3.79(1 \mathrm{H}, \mathrm{m}), 3.80-3.89(1 \mathrm{H}, \mathrm{m})$, $3.91(1 \mathrm{H}, \mathrm{m}) .{ }^{13} \mathrm{C}$ NMR $\left(\mathrm{D}_{2} \mathrm{O}, 100 \mathrm{MHz}\right), \delta 20.3,32.9,30.7$, $48.9,54.8,61.6,65.2,66.1,71.8$.

6-Oxo-2,3,6,7,7a,8-hexahydro-1H,4H-3a-aza-sindacene8a-carboxylic acid methyl ester (3)

In a $100 \mathrm{~mL}$ flask with $\mathrm{Co}_{2}(\mathrm{CO})_{8}(0.05 \mathrm{mmol})$ in dry THF $(10 \mathrm{~mL})$ under nitrogen atmosphere at room temperature was added dropwise a solution of $\mathbf{1 6}(0.50 \mathrm{mmol})$ in THF $(1.0 \mathrm{~mL})$, and [BMIm] $\mathrm{PF}_{6}(0.300 \mathrm{~g})$ in one portion. After $2 \mathrm{~h}$ of stirring at room temperature, NMO $(0.05 \mathrm{mmol})$ was added in one portion. The resulting suspension was quickly purged with $\mathrm{CO}$ and stirred vigorously for $48 \mathrm{~h}$ at room temperature. Substrate consumption was monitored by GC after sampling $100 \mu \mathrm{L}$ of the reaction mixture with a syringe and extracting the organic phase with diethylether. Upon completion of the reaction the organic products were extracted with diethyl ether $(20 \times 5 \mathrm{~mL})$. The solvent was removed under reduced pressure, and the crude product was purified by flash column chromatography (eluting with hexane: EtOAc, 1:1) to give enone 3 in $89 \%$ yield as a yellow crystal. $\mathrm{mp} 85-87^{\circ} \mathrm{C} .[\alpha]_{\mathrm{D}}+35\left(c 1 \cdot 0, \mathrm{CHCl}_{3}\right)$. FTIR $(\mathrm{KBr}) v_{\max } / \mathrm{cm}^{-1}: 2950,1710,1635 .{ }^{1} \mathrm{H}$ NMR $(400 \mathrm{MHz}$ $\left.\mathrm{CDCl}_{3}\right), \delta 1.35(1 \mathrm{H}, \mathrm{t}, J 12.1 \mathrm{~Hz}), 1.70-2.18(5 \mathrm{H}, \mathrm{m})$, 2.56-2.68 (2H, m), 2.71-2.75 (1H, m), $2.90(1 \mathrm{H}, \mathrm{dd}, J 7.2$, $16.0 \mathrm{~Hz}), 3.12-3.18(1 \mathrm{H}, \mathrm{m}), 3.77(3 \mathrm{H}, \mathrm{s}), 3.77-3.93(2 \mathrm{H}$, m), $6.00\left(1 \mathrm{H}\right.$, br s). ${ }^{13} \mathrm{CNMR}\left(400 \mathrm{MHz}, \mathrm{CDCl}_{3}\right), \delta 21.1$, 36.6, 38.3, 38.6, 42.2, 47.9, 50.0, 52.3, 67.5, 128.1, 174.3, $175.4\left(\mathrm{CO}_{2} \mathrm{Me}\right), 205.7$. HRMS, ESI-(+)-MS: $\mathrm{m} / \mathrm{z}$ calc. for $\left[\mathrm{C}_{13} \mathrm{H}_{17} \mathrm{O}_{3} \mathrm{~N}+\mathrm{H}\right]^{+}$236, 1287; found: 236, 1280.

\section{Acknowledgments}

L.S.S. thanks FONDECYT (Project 1085308), IFS (F/4195-1), the Organisation for the Prohibition of Chemical
Weapons. PBCT (PSD-50) was also acknowledged for financial support to S.N.; E.F.D.L thanks Programa de Doctorado en Productos Bioactivos-UTalca for financial support.

\section{References}

1. Adessi, C.; Soto, C.; Curr. Med. Chem. 2002, 9, 963.

2. Kastin, A. J., ed.; Handbook of Biologically Active Peptides, Academic Press: London, 2006.

3. Karoyan, P.; Sagan, S.; Lequin, O.; Quancard, J.; Lavielle, S.; Chassaing, G. In Targets in Heterocyclic Systems-Chemistry and Properties; Attanasi, O. A.; Spinelli, D., eds.; Royal Society of Chemistry: Cambridge, 2005, Vol. 8, pp. 216-273; Cativiela, C.; Díaz-de-Villegas, M. D.; Tetrahedron: Asymmetry 2000, 11, 645.

4. Hill, R. K. In Comprehensive Organic Synthesis; Trost, B. M.; Fleming, I., eds.; Pergamon: Oxford, 1991, Vol. 5, ch. 7.1.

5. Amedjkouh, M.; Ahlberg, P.; Tetrahedron: Asymmetry 2002, 13,2229

6. Vanecko, J. A.; Wan, H.; West, F. G.; Tetrahedron 2006, 62, 1043; Zaragoza, F.; Tetrahedron 1997, 53, 3425.

7. Santos, L. S.; Neto, B. A. D.; Consorti, C. S.; Pavam, C. H.; Almeida, W. P.; Coelho, F.; Dupont, J.; Eberlin, M. N.; J. Phys. Org. Chem. 2006, 19, 731.

8. Corey, E. J.; Link, J. O.; J. Org. Chem. 1991, 56, 442.

9. Shankaraiah, N.; Santos, L. S.; Tetrahedron Lett. 2009, 50, 520; Gozzo, F. C.; Santos, L. S.; Augusti, R.; Consorti, C. S.; Dupont, J.; Eberlin, M. N.; Chem. Eur. J. 2004, 10, 6187; Neto, B. A. D.; Santos, L. S.; Nachtigall, F. M.; Eberlin, M. N.; Dupont, J.; Angew. Chem., Int. Ed. 2006, 45, 7251; Santos, L. S.; Pilli, R. A.; Synthesis 2002, 87.

10. Wright, D. L.; Weekly, R. M.; Groff, R.; McMills, M. C.; Tetrahedron Lett.1996, 37, 2165. Gawley, R. E.; Zhang, Q.; Campagna, S.; J. Am. Chem. Soc. 1995, 117, 11817; West, F. G.; Naidu, B. N.; J. Org. Chem. 1994, 59, 6051; Beall, L. S.; Padwa, A.; Tetrahedron Lett. 1998, 39, 4159.

11. Arboré, A. P. A.; Cane-Honeysett, D. J.; Coldham, I.; Middleton, M. L.; Synlett 2000, 36.

12. Glaeske, K. W.; West, F. G.; Org. Lett. 1999, 1, 31.

13. Coleman, R. S.; Carpenter, A. J.; J. Org. Chem. 1992, 57, 5813.

14. Pandit, U. K.; Overkleeft, H. S.; Borer, B. C.; Bieraugel, H.; Eur. J. Org. Chem. 1999, 5, 959.

15. The spectroscopic data is in accordance with: Groaning, M. D.; Meyers, A. I.; Chem. Commun. 2000, 1027.

16. Santos, L. S.; Pilli, R. A.; J. Braz. Chem. Soc. 2003, 14, 982.

17. Langlois, N.; Nguyen, B. K. L.; Retailleau, P.; Tarnus, C.; Salomon, E.; Tetrahedron: Asymmetry 2006, 17, 53.

18. Spectroscopic data for $\mathbf{1 5}$ is in accordance with: Hoffmann, T.; Lanig, H.; Waibel, R.; Gmeiner, P.; Angew. Chem., Int. Ed. 2001, 40, 3361. 
19. Spectroscopic data for $\mathbf{4}$ is in accordance with reference 17.

20. Shankaraiah, N.; da Silva, Wender A.; Andrade, C. K. Z.; Santos, L. S.; Tetrahedron Lett. 2008, 49, 4289; Ege, M.; Wanner, K. T.; Org. Lett. 2004, 6, 3553.

21. Chung, Y. K.; Lee, B. Y.; Jeong, N.; Hudecek, M.; Pauson, P. L.; Organomettalics 1993, 12, 220.
22. Santos, L. S.; Pilli, R. A.; Rawal, V. H.; J. Org. Chem. 2004, 69, 1283; Santos, L. S., Pilli, R. A.; Tetrahedron Lett. 2001, 42, 6999.

Received: January 19, 2009 Web Release Date: April 17, 2009 